\title{
Pengaruh Metode Pengendalian Gulma terhadap Dominansi Gulma serta Pertumbuhan dan Hasil Tanaman Kedelai (Glycine max (L.) Merr.)
}

\author{
The Effect of Weed Control Methods on Weed Dominance, Growth and Yield \\ of Soybean (Glycine max (L.) Merr.)
}

\author{
Dela Yusuf Efendy, Prapto Yudono, Dyah Weny Respatie*) \\ Departemen Budidaya Pertanian, Fakultas Pertanian, Universitas Gadjah Mada \\ Jalan Flora No. 1, Bulaksumur, Sleman, Yogyakarta 55281, Indonesia \\ *)Penulis untuk korepondensi E-mail: wenyrespatie@ugm.ac.id.
}

\begin{abstract}
This research aimed to determine the effective and efficient of weed control methods to eliminate competition of weed presence in soybean. This research was conducted in Tri Dharma experiment field, faculty of Agriculture, Universitas Gadjah Mada, Yogyakarta from April-July 2018. This research was used Randomized Complete Block Design with three blocks as replication. The weed control methods were WO (without weed control) as the negative control, W1 (mechanical weed control 1 week after planting), W2 (mechanical weed control 1 and 2 weeks after planting), W3 (mechanical weed control 1, 2 and 3 weeks after planting), W4 (mechanical weed control 1, 2, 3 and 4 weeks after planting), W5 (weed control using the cosmos bioherbicide with concentration $400 \mathrm{~g} \cdot \mathrm{L}^{-1}$ on soybean 1 week after planting), W6 (weed control using chemical herbicide with dosage $300 \mathrm{~mL} \cdot \mathrm{m}^{-2}$ on soybean 1 week after planting), W7 (weed control using chemical herbicide with dosage $300 \mathrm{~mL} \cdot \mathrm{m}^{-2}$ on soybean 1 week after planting), W8 (weed control using chemical herbicide with dosage $400 \mathrm{~mL} . \mathrm{m}^{-2}$ on soybean 1 week after planting), and W9 (full of weed free) as the positive control. The result of this research showed that there were effects between weed control treatment against some variables which were the dry weight of weeds, dry weight of the plant, crop growth rate, productivity, and yield loss. Mechanical weed control treatment on soybean until three weeks after planting (W3) was the most effective and efficient method to suppress weed growth and showed the yield as high as weed free treatment.
\end{abstract}

Keywords: bioherbicide control, herbicide control, mechanical control, weed domination, productivity

\section{INTISARI}

Penelitian ini bertujuan untuk menentukan metode pengendalian gulma yang efektif dan efisien untuk menekan kompetisi yang diakibatkan oleh keberadaan gulma pada pertanaman kedelai. Penelitian ini dilaksanakan di Kebun Tri Dharma Fakultas Pertanian Universitas Gadjah Mada, Banguntapan, Bantul, dan Laboratorium Manajemen dan Produksi Tanaman Departemen Budidaya Pertanian, Fakultas Pertanian, Universitas Gadjah Mada, Daerah Istimewa Yogyakarta pada bulan April hingga Juli 2018. Penelitian menggunakan Rancangan Acak Kelompok Lengkap (RAKL) dengan perlakuan satu faktor dan tiga blok sebagai ulangan. Faktor yang digunakan adalah metode pengendalian 
gulma yakni: Wo (tanpa pengendalian gulma) sebagai kontrol negatif, W1 (pengendalian gulma secara mekanis pada umur kedelai 1 MST), W2 (pengendalian gulma secara mekanis pada umur kedelai 1 dan 2 MST), W3 (pengendalian gulma secara mekanis pada umur kedelai 1, 2, dan 3 MST), W4 (pengendalian gulma secara mekanis pada umur kedelai 1, 2, 3 dan 4 MST), W5 (pengendalian gulma menggunakan bioherbisida kenikir konsentrasi 400 g. $\mathrm{L}^{-1}$ pada umur kedelai $1 \mathrm{MST}$ ), W6 (pengendalian gulma menggunakan herbisida sintetis dosis $200 \mathrm{~mL} \cdot \mathrm{m}^{-2}$ pada umur kedelai $1 \mathrm{MST}$ ), W7 (pengendalian gulma menggunakan herbisida sintetis dosis $300 \mathrm{~mL} \cdot \mathrm{m}^{-2}$ pada umur kedelai $1 \mathrm{MST}$ ), W8 (pengendalian gulma menggunakan herbisida sintetis dosis $400 \mathrm{~mL} \cdot \mathrm{m}^{-2}$ pada umur kedelai $1 \mathrm{MST}$ ), dan W9 (perlakuan bebas gulma) sebagai kontrol positif. Hasil penelitian menunjukkan adanya pengaruh antara perlakuan pengendalian gulma terhadap bobot kering gulma, bobot kering tanaman, laju pertumbuhan tanaman, produktivitas, dan kehilangan hasil tanaman kedelai. Perla kuan pengendalian gulma secara mekanis hingga umur 3 MST (W3) paling efektif dan efisien menekan pertumbuhan gulma dan menghasilkan produktivitas tanaman kedelai setara dengan perlakuan bebas gulma.

Kata kunci: dominansi gulma, pengendalian bioherbisida, pengendalian herbisida, pengendalian mekanis, produktivitas

\section{PENDAHULUAN}

Gulma dikenal sebagai tumbuhan yang keberadaannya dapat mengganggu pertumbuhan dan menurunkan produktivitas tanaman budidaya. Keberadaan gulma mengakibatkan terjadinya kompetisi pemanfaatan hara, air, cahaya, dan ruang tumbuh. Tidak jarang beberapa spesies gulma menghasilkan metabolit sekunder yang mampu menghambat pertumbuhan tanaman budidaya, atau yang biasa disebut sebagai peristiwa alelopati. Menurut Moenandir (1993) cit. Hendrival et al., (2014) kerugian yang diakibatkan oleh gulma pada pertanaman ke delai mencapai $80 \%$. Hal ini tentu sangat merugikan mengingat bahwa pada tahun 2015, Riniarsi (2015) melaporkan terjadi defisit kedelai sebesar 1,326 juta ton dan diperkirakan akan terjadi defisit sebesar 1,933 juta ton pada tahun 2019. Sehingga upaya pengendalian gulma pada pertanaman kedelai dinilai perlu, guna mencukupi kebutuhan kedelai nasional.

Kedelai merupakan sumber protein nabati yang dikonsumsi dalam jumlah yang cukup besar. Menurut Anonim (2006), dalam kedelai terkadung vitamin A, B, E dan K serta beberapa jenis mineral seperti $\mathrm{K}, \mathrm{Fe}, \mathrm{P}$, dan $\mathrm{Zn}$ dalam jumlah yang tinggi tetapi dengan kandungan asam lemak jenuh yang rendah. Sekitar $60 \%$ kandungan asam lemak tidak jenuh dalam kedelai terdiri dari asam linoleate dan asam linolenat. Diketahui bahwa kedua asam tidak jenuh tersebut membantu kesehatan jantung. Serta tidak ditemukan adanya kandungan kolesterol dalam kedelai, sehigga mengkonsumsi kedelai baik bagi kesehatan. Atun (2009), menjelaskan bahwa dalam produk olahan kedelai 
terkandung senyawa isoflavon yang memiliki potensi digunakan dalam bidang kesehatan sebagai anti inflamasi, anti tumor, anti kanker, anti alergi, anti kolesterol, memperlancar sirkulasi darah, serta menghambat proses osteoporosis.

Upaya pengendalian gulma merupakan kegiatan yang ditujukan untuk menekan atau mematikan pertumbuhan gulma, sehingga keberadaannya tidak berpengaruh secara signifikan terhadap pertumbuhan dan perkembangan tanaman budidaya. Salah satu pengendalian gulma yang paling sering dilakukan oleh petani adalah pengendalian gulma secara mekanis baik menggunakan tangan secara langsung maupun dengan batuan alat seperti gratul, gosrok, atau cangkul. Pengendalian gulma secara mekanis merupakan kegiatan merusak bagian - bagian gulma yang bertujuan untuk menekan pertumbuhan gulma tersebut (Sukman, 2003). Pengendalian gulma dapat dilakukan dengan beberapa metode diantaranya adalah pengendalian secara mekanik maupun pengendalian dengan menggunakan herbisida.

Seiring dengan berkembangnya ilmu pengetahuan, para peneliti berusaha menemukan alternatif pengendalian gulma yang efektif dan ramah lingkungan, yakni dengan memanfaatkan sifat alelokimia dari tanaman atau tumbuhan lain. Menurut Kaisoon et al. (2012) cit. Lim (2014) dalam bunga kenikir (Cosmos sulphureus Cav.) terkandung beberapa jenis asam fenol berupa: asam gallic $(9,25 \mathrm{mg})$, asam protocatechuic $(3,26 \mathrm{mg})$, asam p-hydroxybenzoic $(2,74 \mathrm{mg})$, asam chlorogenic $(6,90$ $\mathrm{mg})$, asam caffeic $(13,88 \mathrm{mg})$, asam syringic $(2,91 \mathrm{mg})$, asam p-coumaric $(137 \mathrm{mg})$, asam ferulic $(27,85 \mathrm{mg})$, dan asam sinapic $(5,88 \mathrm{mg})$ dengan total 210,27 mg.100 g-1 ekstrak bunga kenikir (Cosmos sulphureus Cav.). Senyawa fenol merupakan jenis alelokimia yang dapat menghambat kerja enzim pertumbuhan indol asetat (IAA) dan asam giberelin (GA) (Sastroutomo, 1990 cit. Hafsah et al., 2012).

Penggunaan herbisida sintetis dinilai sebagai langkah yang praktis dalam menghadapi kehadiran gulma pada tanaman budidaya. Herbisida merupakan senyawa yang digunakan untuk menghambat pertumbuhan atau mematikan gulma dengan mempengaruhi proses pembelahan sel, perkembangan jaringan, sintesis klorofil, fotosintesis, respirasi yang sangat diperlukan untuk kelangsungan hidup gulma. Salah satu jenis herbisida yang dapat ditemukan di pasaran adalah herbisida berbahan aktif oksiflourfen. Menurut Roviyanti dan Widaryanto (2018), aplikasi herbisida berbahan aktif oksiflourfen sangat efektif untuk menekan pertumbuhan gulma pada budidaya tanaman brokoli, aplikasi herbisida berbahan aktif oksiflourfen dapat menghambat pertumbuhan gulma hingga $92,36 \%$ dan meningkatkan hasil sebesar $59,78 \%$. 


\section{BAHAN DAN METODE}

Alat - alat yang digunakan dalam penelitian ini antara lain cangkul, gembor, grathul, oven, blender, gelas ukur, sprayer, timbangan, frame kawat ukuran $50 \times 50 \mathrm{~cm}$, penggaris, aplikasi ImageJ, dan alat tulis. Bahan yang digunakan antara lain bunga kenikir kuning (C. sulphureus Cav.), kedelai kultivar GEMA, aquadest, pupuk kandang, insektisida, herbisida kimia berbahan oksiflourfen.

Penelitian ini dilakukan menggunakan rancangan acak kelompok lengkap (RAKL) dengan perlakuan satu faktor dan tiga blok sebagai ulangan. Faktor yang digunakan adalah metode pengendalian gulma berupa W0 (tanpa pengendalian gulma) sebagai kontrol negatif, metode pengendalian gulma mekanis yang terdiri dari 4 perlakuan yakni W1 (pengendalian gulma secara mekanis pada umur kedelai $1 \mathrm{MST}$ ); W2 (pengendalian gulma secara mekanis pada umur kedelai 1 dan 2 MST); W3 (pengendalian gulma secara mekanis pada umur kedelai 1, 2, dan 3 MST); W4 (pengendalian gulma secara mekanis pada umur kedelai 1, 2, 3 dan 4 MST), pengendalian gulma menggunakan bioherbisida ektrak bunga kenikir yeng terdiri dari 1 perlakuan yakni W5 (bioherbisida ekstrak bunga kenikir dosis $400 \mathrm{~mL} . \mathrm{m}-2$ pada umur kedelai $1 \mathrm{MST}$ ), metode pengendalian gulma menggunakan herbisida sintetis berbahan aktif oksiflourfen yang terdiri dari 3 perlakuan yakni W6 (herbisida sintetis dosis 200 mL.m-2 pada umur kedelai 1 MST); W7 (herbisida sintetis dosis $300 \mathrm{~mL} . \mathrm{m}-2$ pada umur kedelai 1 MST); W8 (herbisida sintetis dosis $400 \mathrm{~mL} . \mathrm{m}-2$ pada umur kedelai $1 \mathrm{MST}$ ), dan W9 (perlakuan bebas gulma) sebagai kontrol positif.

Dalam tiap blok terdapat 10 petak dengan masing - masing petak berukuran $1 \mathrm{x}$ $4 \mathrm{~m}$, dan jarak tanam kedelai $20 \times 40 \mathrm{~cm}$. Bioherbisida kenikir yang diuji menggunakan ekstrak mahkota bunga kenikir kuning (C. sulphureus Cav.) dengan konsentrasi $40 \%$. Herbisida sintetis yang diuji menggunakan bahan aktif oksiflorfen dengan konsentrasi $0.1 \%$

Parameter pengamatan yang diamati terdiri atas pengamatan gulma berupa analisis vegetasi gulma untuk ditentukan nilai SDR masing-masing gulma dinyatakan dalam $\%$, pengamatan bobot kering gulma dan pengamatan dan hasil tanaman meliputi tinggi tanaman, jumlah daun, luas daun, bobot kering tanaman kedelai, analisis pertumbuhan tanaman kedelai, produktivitas dan kehilangan hasil kedelai akibat keberadaan gulma.

Data yang telah diperoleh kemudian dilakukan uji kenormalan distribusi dan homogenitas varians data. Jika distribusi data normal dan varians cukup homogen, kemudian dilakukan analisis sidik ragam (ANOVA) dengan tingkat kepercayaan 95\%. 
Apabila hasil analisis menunjukkan beda nyata, dilakukan uji kontras dengan tingkat kepercayaan 95\% untuk mengetahui interaksi antar kelompok metode pengendalian gulma. Selanjutnya dilakukan uji lanjut DMRT dengan taraf kepercayaan 95\% untuk mengetahui interaksi antar perlakuan pengendalian gulma.

\section{HASIL DAN PEMBAHASAN}

Keberadaan gulma pada budidaya tanaman kedelai dapat menyebabkan terjadinya penurunan hasil 20 hingga $80 \%$. Hasil penelitian pengaruh tiga metode pengendalian gulma terhadap pertumbuhan dan hasil tanaman kedelai serta dominansi gulma disajikan pada Tabel 1.

Tabel 1 menunjukkan dominansi gulma yang ada pada lahan penelitian sebelum dilakukan olah tanah. Terlihat bahwa pada lahan penelitian terdapat 24 spesies gulma yang berhasil diidentifikasi. Dari berbagai spesies gulma yang ada, diketahui bahwa Dactyloctenium aegyptium, Bulbostylis puberula, dan Cyperus compressus merupakan spesies gulma yang memiliki nilai SDR paling tinggi diantara spesies yang lain. Melalui kemiripan morfologi, jenis gulma yang banyak tumbuh pada lahan penelitian adalah jenis gulma rumputan. Menurut Johny (2006) gulma jenis rumputan memiliki batang menjalar yang terdiri dari buku dan ruas batang, dari buku batang dapat muncul akar dan tunas baru sehingga menjadi individu baru. Dengan demikian semakin panjang rumput dan semakin banyak buku batang akan menghasilkan lebih banyak individu baru. Selain itu, perkembang biakan menggunakan stolon menyebabkan gulma lebih cepat berkembang biak menjadi individu baru sebelum mencapai fase generatif. Hal ini diduga menjadi penyebab tingginya nilai SDR gulma rumputan pada lahan penelitian sebelum dilakukan olah lahan. 
Tabel 1. Analisis Vegetasi Gulma Awal Sebelum Olah Lahan

\begin{tabular}{lccc}
\hline Spesies Gulma & Morfologi Gulma & Siklus Hidup & SDR (\%) \\
\hline Borreria alata & $\mathrm{D}$ & $\mathrm{S}$ & 2,29 \\
Bulbostylis puberula & $\mathrm{T}$ & $\mathrm{S}$ & 10,18 \\
Cleome aspera & $\mathrm{D}$ & $\mathrm{S}$ & 1,59 \\
Croton hirtus & $\mathrm{D}$ & $\mathrm{S}$ & 1,64 \\
Cynodon dactylon & $\mathrm{R}$ & $\mathrm{Th}$ & 1,37 \\
Cyperus compressus & $\mathrm{T}$ & $\mathrm{Th}$ & 10,17 \\
Cyperus iria & $\mathrm{T}$ & $\mathrm{S}$ & 1,63 \\
Cyperus rotundus & $\mathrm{T}$ & $\mathrm{Th}$ & 1,91 \\
Dactyloctenium aegyptium & $\mathrm{R}$ & $\mathrm{S}$ & 19,93 \\
Digitaria sanguinalis & $\mathrm{R}$ & $\mathrm{S}$ & 8,78 \\
Eleusin indica & $\mathrm{R}$ & $\mathrm{S}$ & 5,63 \\
Eragrostis tenella & $\mathrm{R}$ & $\mathrm{S}$ & 4,16 \\
Euphorbia hirta & $\mathrm{D}$ & $\mathrm{S}$ & 2,38 \\
Ischaemum timorense & $\mathrm{R}$ & $\mathrm{Th}$ & 7,04 \\
Lindernia ciliate & $\mathrm{D}$ & $\mathrm{S}$ & 1,96 \\
Lindernia crustacea & $\mathrm{D}$ & $\mathrm{S}$ & 1,84 \\
Melochia pyramidata & $\mathrm{D}$ & $\mathrm{Th}$ & 0,79 \\
Ocimum sanctum & $\mathrm{D}$ & $\mathrm{S}$ & 3,76 \\
Oldenlandia dichotoma & $\mathrm{D}$ & $\mathrm{Th}$ & 3,97 \\
Panicum sp & $\mathrm{R}$ & $\mathrm{S}$ & 2,43 \\
Phyllanthus niruri & $\mathrm{S}$ & 2,37 \\
Phyllanthus urinaria & $\mathrm{D}$ & $\mathrm{S}$ & 0,69 \\
Richardia scabra & $\mathrm{D}$ & $\mathrm{S}$ & 0,76 \\
Vernonia cinereal & $\mathrm{D}$ & & 26,77 \\
\hline Daun Lebar & & & 49,34 \\
Rumputan & & & 23,89 \\
Tekian & & & 73,32 \\
\hline Semusim & & & 26,68 \\
Tahunan & & & \\
Keterangan: D (Daun Lebar), R (Rumputan), T (Tekian); S (Semusim) & Th (Tahunan) \\
\hline
\end{tabular}

Dibandingkan dengan gulma yang memiliki siklus hidup tahunan, gulma semusim merupakan jenis gulma yang dominan pada lahan penelitian sebelum dilakukan olah lahan. Menurut Radjit dan Purwaningrahayu (2016), gulma semusim merupakan jenis gulma yang paling sering ditemukan di pertanaman tanaman pangan, jenis gulma semusim memiliki kemampuan tumbuh yang cepat dan mampu menghasilkan biji dalam waktu yang singkat. Sehingga pada lahan yang digunakan untuk penelitian lebih didominasi oleh gulma yang memiliki siklus hidup semusim dibandingkan gulma yang memiliki siklus hidup tahunan. 
Tabel 2. SDR Gulma pada Berbagai Metode Pengendalian Gulma (\%)

\begin{tabular}{|c|c|c|c|c|c|c|c|c|c|c|c|}
\hline Spesies Gulma & $\begin{array}{c}\text { Morfologi } \\
\text { Gulma }\end{array}$ & $\begin{array}{l}\text { Siklus } \\
\text { Hidup }\end{array}$ & Wo & W1 & W2 & W3 & W4 & W5 & W6 & W7 & W8 \\
\hline Amaranthus spinosus & D & $S$ & 3,12 & 4,33 & 3,60 & 9,52 & 11,80 & 4,01 & 3,96 & 0,00 & 3,42 \\
\hline Boerhavia erecta & $\mathrm{D}$ & $S$ & 4,34 & 3,16 & 4,89 & 0,00 & 4,96 & 0,76 & 1,26 & 0,00 & 0,00 \\
\hline Borreria alata & $D$ & $S$ & 1,35 & 1,71 & 1,87 & 2,77 & 1,38 & 0,90 & 0,00 & 0,00 & 0,00 \\
\hline Bulbostilis puberula & $\mathrm{T}$ & $S$ & 6,13 & 8,30 & 1,41 & 0,00 & 0,72 & 1,26 & 0,00 & 0,00 & 0,78 \\
\hline Cleome aspera & $\mathrm{D}$ & $S$ & 2,50 & 2,34 & 2,17 & 0,00 & 4,63 & 2,82 & 0,00 & 3,25 & 0,96 \\
\hline Croton hirtus & $\mathrm{D}$ & $S$ & 2,85 & 3,37 & 1,55 & 1,60 & 1,05 & 1,50 & 0,00 & 0,00 & 0,00 \\
\hline Cynodon dactilon & $\mathrm{R}$ & Th & 4,34 & 1,42 & 5,22 & 10,39 & 3,05 & 4,70 & 11,82 & 8,13 & 2,58 \\
\hline Cyperus compressus & $\mathrm{T}$ & Th & 5,27 & 4,05 & 2,02 & 0,00 & 1,86 & 2,15 & 0,85 & 0,00 & 1,77 \\
\hline Cyperus iria & $\mathrm{T}$ & $S$ & 1,26 & 1,31 & 0,00 & 0,77 & 0,00 & 0,68 & 1,00 & 0,00 & 0,00 \\
\hline Cyperus rotundus & $\mathrm{T}$ & Th & 3,63 & 2,83 & 7,09 & 8,70 & 7,10 & 9,15 & 10,83 & 9,33 & 8,66 \\
\hline Dactiloctenium aegyptium & $\mathrm{R}$ & $S$ & 15,55 & 24,60 & 13,90 & 12,39 & 14,412 & 25,49 & 29,85 & 37,13 & 35,76 \\
\hline Digitaria sanguinalis & $\mathrm{R}$ & $S$ & 16,18 & 10,00 & 22,99 & 9,86 & 11,811 & 16,49 & 12,88 & 23,07 & 7,43 \\
\hline Eleusine indica & $\mathrm{R}$ & $S$ & 9,25 & 7,82 & 7,67 & 8,14 & 5,69 & 13,29 & 10,36 & 8,36 & 10,33 \\
\hline Eragrostis tenella & $\mathrm{R}$ & $S$ & 3,18 & 2,09 & 1,26 & 0,91 & 2,79 & 3,11 & 2,28 & 0,00 & 2,01 \\
\hline Euphorbia heterophylla & $\mathrm{D}$ & $S$ & 0,31 & 1,35 & 0,00 & 1,88 & 1,57 & 0,00 & 0,00 & 0,00 & 0,79 \\
\hline Euphorbia hirta & $\mathrm{D}$ & $S$ & 2,41 & 1,79 & 1,53 & 1,91 & 0,71 & 2,01 & 0,00 & 1,67 & 0,81 \\
\hline Ginandropsis ginandra & $\mathrm{D}$ & $S$ & 0,00 & 1,02 & 1,11 & 0,00 & 0,78 & 0,97 & 0,85 & 0,00 & 1,66 \\
\hline Ischaemum timorense & $\mathrm{R}$ & Th & 0,39 & 0,00 & 0,00 & 0,00 & 0,00 & 0,00 & 0,00 & 0,00 & 0,00 \\
\hline Lindernia cilliata & $\mathrm{D}$ & $S$ & 0,62 & 0,00 & 0,00 & 0,00 & 0,00 & 0,00 & 0,00 & 0,00 & 0,00 \\
\hline Lindernia crustacea & $\mathrm{D}$ & $S$ & 0,32 & 0,41 & 0,00 & 0,00 & 0,00 & 0,00 & 0,00 & 0,00 & 0,00 \\
\hline Melocia pyramidata & $\mathrm{D}$ & $S$ & 0,63 & 0,81 & 2,00 & 2,67 & 1,54 & 0,00 & 0,00 & 0,00 & 0,00 \\
\hline Ocymum sanctum & $\mathrm{D}$ & Th & 1,87 & 1,86 & 0,53 & 0,00 & 1,41 & 0,62 & 0,81 & 1,58 & 0,00 \\
\hline Oldenlandia dicotoma & $\mathrm{D}$ & $S$ & 1,14 & 0,74 & 0,50 & 0,77 & 0,76 & 0,00 & 0,00 & 0,00 & 0,00 \\
\hline Panicum sp & $\mathrm{R}$ & Th & 5,09 & 6,92 & 8,29 & 19,44 & 15,90 & 4,16 & 7,71 & 2,34 & 16,58 \\
\hline Phyllanthus niruri & D & $S$ & 1,92 & 2,11 & 2,14 & 0,00 & 2,20 & 1,29 & 0,00 & 0,00 & 1,67 \\
\hline Physalis peruviana & $\mathrm{D}$ & $S$ & 0,64 & 1,13 & 0,92 & 3,61 & 0,00 & 1,74 & 0,00 & 0,00 & 0,00 \\
\hline Richardia scabra & $\mathrm{D}$ & $S$ & 5,73 & 4,53 & 7,32 & 4,66 & 3,88 & 2,91 & 5,53 & 5,14 & 4,77 \\
\hline Daun Lebar & & & 29,74 & 30,66 & 30,16 & 29,39 & 36,67 & 19,52 & 12,42 & 11,63 & 14,09 \\
\hline Rumputan & & & 53,98 & 52,85 & 59,33 & 61,13 & 53,66 & 67,24 & 74,90 & 79,03 & 74,70 \\
\hline Tekian & & & 16,29 & 16,48 & 10,52 & 9,48 & 9,67 & 13,24 & 12,68 & 9,33 & 11,22 \\
\hline Semusim & & & 79,41 & 82,93 & 76,85 & 61,47 & 70,687 & 79,22 & 67,98 & 78,62 & 70,41 \\
\hline Tahunan & & & 20,59 & 17,07 & 23,15 & 38,53 & 29,322 & 20,78 & 32,02 & 21,38 & 29,59 \\
\hline $\begin{array}{ll}\text { Total Biomassa }(\mathrm{g}) \\
\text { Keterangan: } & \mathrm{D} \text { (Daun Le } \\
& \text { pengendalia } \\
& 3 \mathrm{MST}), \mathrm{W} 4 \\
& \text { (Herbisida O } \\
& \text { Oksiflourfen }\end{array}$ & $\begin{array}{l}\text { ), R ( } \\
\text { ulma), } \\
\text { lekanis } \\
\text { flourfe }\end{array}$ & $M$ & $\frac{45,10}{\mathrm{n}), \mathrm{T}(\mathrm{r}}$ & $\frac{30,82}{\text { Tekian); }}$ & $\begin{array}{r}29,90 \\
\text { ) S (S } \\
\text { N2 (Mel }\end{array}$ & $\frac{19,44}{\text { emusir }}$ & $\begin{array}{l}20,972 \\
\mathrm{~m}), \mathrm{Th} \\
1 \& 2 \mathrm{M}\end{array}$ & $\begin{array}{l}24,59 \\
\text { h (Tahu } \\
\text { MST), V }\end{array}$ & 22,88 & $\frac{9,39}{\text { Wo }}$ & $\begin{array}{r}26,43 \\
\text { (Tanpa } \\
1,2 \&\end{array}$ \\
\hline
\end{tabular}


Pengaruh perlakuan pengendalian gulma terhadap dominansi gulma ketika umur 9 MST dapat diamati melalui Tabel 2. Pada lahan perlakuan tanpa pengendalian gulma (W0) didominasi oleh gulma spesies Digitaria sanguinalis dengan nilai SDR yang tidak berbeda jauh terhadap spesies Dactiloctenium aegyptium. Berdasarkan kemiripan morfologi gulma, pada lahan perlakuan tanpa pengendalian gulma didominasi oleh kelompok gulma rumputan. Sedangkan berdasar pada siklus hidup gulma, pada lahan perlakuan tanpa pengendalian gulma didominasi oleh kelompok gulma semusim yang memiliki jumlah nilai SDR lebih tinggi dibanding gulma tahunan. Pada lahan tersebut ditemukan beberapa spesies gulma yang tidak tumbuh ketika pengamatan sebelum olah lahan, antara lain: Amaranthus spinosus, Boerhavia erecta, dan Physalis peruviana.

Berdasarkan pada Tabel 2, masing - masing lahan perlakuan memiliki spesies gulma dominan berbeda. Spesies gulma dominan pada lahan perlakuan mekanis W1 adalah Dactiloctenium aegyptium. Spesies gulma dominan pada lahan perlakuan W2 sama seperti spesies gulma dominan pada lahan perlakuan W0, yakni spesies Digitaria sanguinalis merupakan spesies gulma yang memiliki nilai SDR paling tinggi. Pada lahan perlakuan W3 dan W4 Panicum sp. merupakan spesies gulma yang memiliki nilai SDR paling tinggi diantara spesies lain. Mirip dengan lahan perlakuan W1, pada lahan perlakuan W5, W6, W7, dan W8 juga didominasi oleh gulma spesies Dactiloctenium aegyptium. Berdasarkan kemiripan morfologi yang dimiliki oleh masing - masing spesies gulma, diketahui bahwa paada lahan perlakuan W0 hingga W8 didominasi oleh kelompok gulma rumputan. Sedangkan berdasar siklus hidup gulma, pada seluruh perlakuan didominasi oleh kelompok gulma semusim.

Biomassa gulma yang dihasilkan dari masing - masing perlakuan menunjukkan jumlah bobot kering gulma sampel dari seluruh spesies. Hasil uji kontras pada Tabel 3, menunjukkan bahwa pada pengamatan umur 4 MST biomassa gulma yang dihasilkan oleh perlakuan tanpa pengendalian gulma (W0) berbeda nyata dibandingkan dengan perlakuan pengendalian gulma. Berdasar hasil uji DMRT diketahui bahwa perlakuan yang menghasilkan biomassa gulma berbeda nyata dengan perlakuan WO adalah perlakuan W2 hingga perlakuan W9. Hasil uji kontras menunjukkan perbandingan biomassa gulma perlakuan W1 terhadap perlakuan $\mathrm{W} 2$, W3, dan W4 berbeda nyata. Diketahui bahwa hasil uji DMRT menunjukkan biomassa gulma perlakuan W1 setara dengan biomassa gulma perlakuan WO. Biomassa gulma yang dihasilkan oleh perlakuan W2 berbeda nyata jika dibandingkan dengan biomassa gulma perlakuan W3 dan W4. 
Tabel 3. Total Biomassa Gulma

\begin{tabular}{|c|c|c|c|}
\hline Perlakuan & $4 \mathrm{MST}$ & $7 \mathrm{MST}$ & $9 \mathrm{MST}$ \\
\hline W0 VS Pengendalian & $30,74^{*}$ & 19,24 * & 24,57 * \\
\hline Mekanis VS (Sintetis \& Bioherbisida) & $2,14 \mathrm{~ns}$ & $0,23 \mathrm{~ns}$ & 5,56 * \\
\hline W1 VS (W2, W3, \& W4) & 50,94 * & 27,25 * & $2,06 \mathrm{~ns}$ \\
\hline W2 VS (W3 \& W4) & $18,78^{*}$ & 15,50 * & $4,33 \mathrm{~ns}$ \\
\hline W3 VS W4 & $2,02 \mathrm{~ns}$ & $2,88 \mathrm{~ns}$ & $0,22 \mathrm{~ns}$ \\
\hline W5 VS (W6, W7, \& W8) & $2,43 \mathrm{~ns}$ & 3,97 * & $3,72 \mathrm{~ns}$ \\
\hline W6 VS (W7 \& W8) & $0,21 \mathrm{~ns}$ & $0,02 \mathrm{~ns}$ & 5,18 * \\
\hline W7 VS W8 & $0,87 \mathrm{~ns}$ & $1,03 \mathrm{~ns}$ & 22,96 * \\
\hline W9 VS Pengendalian & $72,73^{*}$ & 81,71 * & 111,16 * \\
\hline W0 (Tanpa pengendalian gulma) & $37,38 a$ & $34,35 a$ & $45,10 a$ \\
\hline W1 (Mekanis $1 \mathrm{MST}$ ) & $36,62 a$ & $34,89 a$ & $30,82 \mathrm{ab}$ \\
\hline W2 (Mekanis $1 \& 2$ MST) & $17,46 \mathrm{~b}$ & $24,52 a b$ & $29,90 \mathrm{ab}$ \\
\hline W3 (Mekanis 1, 2 \& 3 MST) & $2,34 \mathrm{c}$ & $5,27 \mathrm{e}$ & $19,44 \mathrm{~b}$ \\
\hline W4 (Mekanis 1, 2, 3 \& 4 MST) & $6,31 \mathrm{c}$ & $10,44 \mathrm{de}$ & $20,97 b$ \\
\hline W5 (Bioherbisida Bunga Kenikir) & $20,62 b$ & $21,50 \mathrm{~b}$ & $24,59 \mathrm{~b}$ \\
\hline W6 (Herbisida Oksiflourfen $200 \mathrm{~mL} \cdot \mathrm{m}^{-2}$ ) & $14,62 b$ & $14,99 \mathrm{bcd}$ & $22,88 b$ \\
\hline W7 (Herbisida Oksiflourfen $300 \mathrm{~mL} \cdot \mathrm{m}^{-2}$ ) & $14,32 b$ & 11,67 cde & $9,93 \mathrm{c}$ \\
\hline W8 (Herbisida Oksiflourfen $400 \mathrm{~mL} \cdot \mathrm{m}^{-2}$ ) & $18,03 b$ & $15,32 \mathrm{bcd}$ & $26,43 \mathrm{~b}$ \\
\hline W9 (Bebas gulma) & $0,00 d$ & $0,00 \mathrm{f}$ & $0,00 \mathrm{~d}$ \\
\hline
\end{tabular}

Keterangan: angka yang diikuti tanda $\left({ }^{*}\right)$ berbeda nyata, angka yang diikuti huruf (ns) tidak berbeda nyata pada uji kontras dengan taraf kepercayaan 95\%; angka yang diikuti huruf yang sama pada kolom yang sama, tidak berbeda nyata pada uji DMRT pada taraf kepercayaan $95 \%$

Pada pengamatan umur 7 MST diketahui bahwa biomassa gulma perlakuan tanpa pengendalian gulma berbeda nyata dibandingkan dengan biomassa gulma yang dihasilkan perlakuan pengendalian gulma (Tabel 3). Perlakuan yang menghasilkan biomassa gulma berbeda nyata dengan perlakuan W0 adalah perlakuan W3 hingga perlakuan W9. Sedangkan perlakuan W1 dan W2 diketahui menghasilkan biomassa gulma setara dengan perlakuan W0. Perlakuan W1 dan W2 menghasilkan biomassa gulma yang berbeda nyata dibandigkan dengan perlakuan W3 dan W4. Dari seluruh perlakuan yang diuji, diketahui bahwa tidak ada perlakuan yang menghasilkan biomassa gulma yang setara dengan perlakuan W9.

Pengamatan biomassa gulma ketika umur 9 MST menunjukkan bahwa perbandingan biomassa yang dihasilkan perlakuan tanpa pengendalian gulma (W0) berbeda nyata dengan biomassa gulma yang dilakukan perlakuan pengendalian gulma. Perlakuan pengendalian gulma yang menhasilkan biomassa gulma berbeda nyata dengan perlakuan W0 adalah perlakuan W3 hingga W9. Sedangkan perlakuan W1 dan W2 menghasilkan biomassa gulma setara dengan perlakuan W0. Perbandingan biomassa gulma perlakuan pengendalian mekanis dengan perlakuan herbisida (sintetis dan bioherbisida) menunjukkan hasil beda nyata, diketahui bahwa perlakuan W7 
menghasilkan biomassa gulma yang berbeda nyata terhadap biomassa gulma yang dihasilkan perlakuan lain. Pada pengamatan umur 9 MST, tidak ditemukan perlakuan yang menghasilkan biomassa gulma yang setara dengan perlakuan W9.

Gulma jenis rumputan merupakan jenis gulma yang dominan pada seluruh perlakuan kecuali pada perlakuan W9. Diketahui bahwa gulma rumputan memiliki perbanyakan vegetatif melalui tuber yang muncul dari ruas batang. Berbeda dari gulma jenis tekian yang memiliki perbanyakan vegetatif melalui umbi, kecepatan perbanyakan vegetatif gulma rumputan cenderung lebih cepat. Hal ini disebabkan karena gulma jenis rumputan mempu menghasilkan anakan melalui tuber yang tumbuh dari setiap ruas batangnya. Hal ini dibuktikan dengan nilai SDR gulma rumputan paling tinggi pada seluruh perlakuan. Berdasarkan siklus hidupnya, gulma semusim merupakan gulma dominan pada seluruh lahan perlakuan. Gulma semusim memiliki siklus hidup yang relatif pendek, sedangkan gulma tahunan memiliki siklus hidup yang panjang. Diduga karena memiliki siklus hidup yang pendek, gulma semusim mampu menghasilkan biji dalam kurun waktu yang lebih singkat. Sedangkan pada jenis gulma tahunan, waktu yang diperlukan untuk menghasilkan biji lebih lama. Adanya sanitasi gulma ketika olah lahan, diduga menyebabkan gulma tahunan mati sebelum menghasilkan biji.

Perlakuan pengendalian gulma W3 hingga W9 terbukti mampu menghambat pertumbuhan gulma secara nyata. Perlakuan W2 secara nyata menghambat pertumbuhan gulma hingga umur 4 MST. Perlakuan W5 hingga W8 menunjukkan penghambatan pertumbuhan gulma daun lebar paling baik diantara perlakuan lain. Penghambatan pertumbuhan gulma jenis daun lebar pada perlakuan W5 hingga W8 menyebabkan jenis gulma dominan tumbuh lebih optimal. Hal ini dibuktikan pada lahan perlakuan tersebut nilai SDR lebih tinggi dari perlakuan lain dengan biomassa gulma akhir yang relative sama. Perlakuan pengendalian gulma menyebabkan terjadinya perubahan komunitas gulma pada masing - masing perlakuan, sehingga menyebabkan komunitas gulma heterogen. 
Efendy et al. / Vegetalika. 2020. 9(3): 449-463

Tabel 4. Bobot Kering Tanaman Kedelai (g) pada Berbagai Metode Pengendalian Gulma

\begin{tabular}{llll}
\hline Perlakuan & $4 \mathrm{MST}$ & $7 \mathrm{MST}$ & $9 \mathrm{MST}$ \\
\hline W0 VS Pengendalian & $0,016 \mathrm{~ns}$ & $0,620 \mathrm{~ns}$ & $0,533^{*}$ \\
Mekanis VS (Sintetis \& Bioherbisida) & $0,462^{*}$ & $0,003 \mathrm{~ns}$ & $0,072 \mathrm{~ns}$ \\
W1 VS (W2, W3, \& W4) & $0,292^{*}$ & $1,998^{*}$ & $1,845^{*}$ \\
W2 VS (W3 \& W4) & $0,004 \mathrm{~ns}$ & $0,006 \mathrm{~ns}$ & $0,002 \mathrm{~ns}$ \\
W3 VS W4 & $0,003 \mathrm{~ns}$ & $0,209 \mathrm{~ns}$ & $0,003 \mathrm{~ns}$ \\
W5 VS (W6, W7, \& W8) & $0,001 \mathrm{~ns}$ & $0,020 \mathrm{~ns}$ & $0,011 \mathrm{~ns}$ \\
W6 VS (W7 \& W8) & $0,001 \mathrm{~ns}$ & $0,026 \mathrm{~ns}$ & $0,003 \mathrm{~ns}$ \\
W7 VS W8 & $0,032 \mathrm{~ns}$ & $0,052 \mathrm{~ns}$ & $0,096 \mathrm{~ns}$ \\
W9 VS Pengendalian & $0,049 \mathrm{~ns}$ & $2,055^{*}$ & $0,364 \mathrm{~ns}$ \\
\hline W0 (Tanpa pengendalian gulma) & $1,37 \mathrm{ab}$ & $3,48 \mathrm{~cd}$ & $4,59 \mathrm{c}$ \\
W1 (Mekanis 1 MST) & $1,26 \mathrm{ab}$ & $2,76 \mathrm{~d}$ & $3,46 \mathrm{c}$ \\
W2 (Mekanis 1 \& 2 MST) & $2,26 \mathrm{a}$ & $6,99 \mathrm{abc}$ & $7,52 \mathrm{ab}$ \\
W3 (Mekanis 1, 2 \& 3 MST) & $2,07 \mathrm{a}$ & $5,91 \mathrm{bc}$ & $8,16 \mathrm{a}$ \\
W4 (Mekanis 1, 2, 3 \& 4 MST) & $2,20 \mathrm{a}$ & $7,88 \mathrm{ab}$ & $7,55 \mathrm{ab}$ \\
W5 (Bioherbisida Bunga Kenikir) & $1,28 \mathrm{ab}$ & $5,26 \mathrm{bcd}$ & $7,36 \mathrm{ab}$ \\
W6 (Herbisida Oksiflourfen 200 mL.m ${ }^{-2}$ ) & $1,28 \mathrm{ab}$ & $6,07 \mathrm{bc}$ & $6,80 \mathrm{ab}$ \\
W7 (Herbisida Oksiflourfen 300 mL.m ${ }^{-2}$ ) & $1,40 \mathrm{ab}$ & $5,93 \mathrm{bc}$ & $7,82 \mathrm{ab}$ \\
W8 (Herbisida Oksiflourfen 400 mL.m -2 ) & $1,07 \mathrm{~b}$ & $5,22 \mathrm{bcd}$ & $6,37 \mathrm{abc}$ \\
W9 (Bebas gulma) & $1,93 \mathrm{ab}$ & $10,41 \mathrm{a}$ & $8,89 \mathrm{a}$
\end{tabular}

Keterangan: angka yang diikuti tanda $\left({ }^{*}\right)$ berbeda nyata, angka yang diikuti huruf (ns) tidak berbeda nyata pada uji kontras dengan taraf kepercayaan $95 \%$; angka yang diikuti huruf yang sama pada kolom yang sama, tidak berbeda nyata pada uji DMRT pada taraf kepercayaan $95 \%$

Pengaruh perlakuan pengendalian gulma terhadap bobot kering tanaman kedelai dapat diamati pada Tabel 4. Pada pengamatan umur 4 MST bobot kering tanaman yang dihasilkan oleh seluruh perlakuan yang diuji tidak berbeda nyata dengn pelakuan tanpa pengendalian gulma (W0). Perbandingan antara perlakuan mekanis dengan perlakuan herbisida sintetis dan bioherbisida menunjukkan bahwa perlakuan W2, W3, dan W4 berbeda nyata dengan perlakuan W8. Sedangkan pada pengamatan umur 7 MST diketahui bahwa perlakuan W4 dan W9 memiliki bobot kering tanaman yang berbedanyata dibandingkan dengan perlakuan W0. Perbandingan antara perlakuan W1 dengan perlakuan W2, W3, dan W4 menunjukkan bahwa perlakuan W1 berbeda nyata dengan perlakuan W2, W3, dan W4. Diketahui bahwa perlakuan W2 dan W4 memiliki bobot kering tanaman setara dengan perlakuan W9.

Pengamatan bobot kering tanaman pada umur 9 MST menunjukkan bahwa perbandingan perlakuan WO dengan perlakuan pengendalian gulma memiliki hasil yang 
berbeda nyata. Perlakuan W1 dan W8 diketahui memiliki bobot kering tanaman yang setara dengan perlakuan W0. Kecuali perlakuan W0 dan W1, seluruh perlakuan yang diuji memiliki bobot kering tanaman yang setara dengan perlakuan W9.

Tabel 5. Laju Pertumbuhan Tanaman Kedelai pada Berbagai Metode Pengendalian Gulma

\begin{tabular}{lll}
\hline Perlakuan & \multicolumn{1}{c}{4 MST } & \multicolumn{1}{c}{$7 \mathrm{MST}$} \\
\hline W0 VS Pengendalian & $0,00000533 \mathrm{~ns}$ & $0,000306^{*}$ \\
Mekanis VS (Sintetis \& Bioherbisida) & $0,00014526^{*}$ & $0,000074 \mathrm{~ns}$ \\
W1 VS (W2, W3, \& W4) & $0,0000907^{*}$ & $0,000751^{*}$ \\
W2 VS (W3 \& W4) & $0,00000132 \mathrm{~ns}$ & $0,000021 \mathrm{~ns}$ \\
W3 VS W4 & $0,00000093 \mathrm{~ns}$ & $0,000108 \mathrm{~ns}$ \\
W5 VS (W6, W7, \& W8) & $0,00000048 \mathrm{~ns}$ & $0,00002 \mathrm{~ns}$ \\
W6 VS (W7 \& W8) & $0,00000009 \mathrm{~ns}$ & $0,000015 \mathrm{~ns}$ \\
W7 VS W8 & $0,00000962 \mathrm{~ns}$ & $0,000008 \mathrm{~ns}$ \\
W9 VS Pengendalian & $0,00001524 \mathrm{~ns}$ & $0,000988^{*}$ \\
\hline W0 (Tanpa pengendalian gulma) & $0,0004 \mathrm{ab}$ & $0,0009 \mathrm{~cd}$ \\
W1 (Mekanis 1 MST) & $0,0004 \mathrm{ab}$ & $0,0006 \mathrm{~d}$ \\
W2 (Mekanis 1 \& 2 MST) & $0,0007 \mathrm{a}$ & $0,0020 \mathrm{bcd}$ \\
W3 (Mekanis 1, 2 \& 3 MST) & $0,0007 \mathrm{a}$ & $0,0016 \mathrm{bcd}$ \\
W4 (Mekanis 1, 2, 3 \& 4 MST) & $0,0007 \mathrm{a}$ & $0,0024 \mathrm{ab}$ \\
W5 (Bioherbisida Bunga Kenikir) & $0,0004 \mathrm{ab}$ & $0,0017 \mathrm{bcd}$ \\
W6 (Herbisida Oksiflourfen 200 mL.m-2) & $0,0004 \mathrm{ab}$ & $0,0022 \mathrm{abc}$ \\
W7 (Herbisida Oksiflourfen 300 mL.m-2) & $0,0004 \mathrm{ab}$ & $0,0019 \mathrm{abcd}$ \\
W8 (Herbisida Oksiflourfen 400 mL.m-2) & $0,0003 \mathrm{~b}$ & $0,0017 \mathrm{bcd}$ \\
W9 (Bebas gulma) & $0,0006 \mathrm{ab}$ & $0,0035 \mathrm{a}$ \\
\hline
\end{tabular}

Keterangan: angka yang diikuti tanda $\left({ }^{*}\right)$ berbeda nyata, angka yang diikuti huruf (ns) tidak berbeda nyata pada uji kontras dengan taraf kepercayaan 95\%; angka yang diikuti huruf yang sama pada kolom yang sama, tidak berbeda nyata pada uji DMRT pada taraf kepercayaan $95 \%$

Tabel 5 menunjukkan pengaruh perlakuan pengendalian gulma terhadap laju pertumbuhan tanaman kedelai. Pengamatan laju pertumbuhan tanaman ledelai ketika umur 4 MST menunjukkan bahwa seluruh perlakuan yang diuji memiliki laju pertumbuhan tanaman yang setara dengan perlakuan tanpa pengendalian gulma (W0). Perbandingan antara perlakuan mekanis dengan perlakuan herbisida sintetis dan bioherbisida menunjukkan bahwa perlakuan W2, W3, dan W4 berbeda nyata dengan perlakuan W8. Kemudian pada pengamatan umur 7 MST, perbandingan perlakuan W0 dengan perlakuan pengendalian gulma memiliki hasil yang berbeda nyata. Diketahui bahwa perlakuan W4 dan W9 memiliki laju pertumbuhan tanaman berbeda nyata 
dibandingkan dengan perlakuan WO. Diketahui bahwa perlakuan yang memiliki laju pertumbuhan tanaman setara dengan pelakuan W9 adalah perlakuan W4, W6, dan W7.

Secara umum, tanaman kedelai yang mendapat cekaman biotik dari keberadaan gulma mengalami gangguan pertumbuhan. Cekaman biotik dari keberadaan gulma cenderung memicu pertumbuhan tinggi tanaman kedelai menjadi lebih optimal pada awal fase pertumbuhan. Akan tetapi, karena adanya kompetisi dengan gulma (ruang tumbuh, cahaya, air, maupun hara) menyebabkan tanaman yang tercekap oleh keberadaan gulma memiliki luas daun yang lebih sempit. Tanaman yang mendapat cekaman biotik tinggi dari keradaan gulma menyebabkan bobot kering rendah. Hal ini diduga terjadi karena adanya kompetisi dengan gulma menyebabkan tanaman tidak mampu memanfaatkan hara dan air secara optimal.

Tabel 6. Produktivitas (ton.ha-1 ${ }^{-1}$ dan Kehilangan Hasil (\%) Tanaman Kedelai pada Berbagai Metode Pengendalian Gulma

\begin{tabular}{lcc}
\hline Perlakuan & Produktivitas & Kehilangan Hasil \\
\hline W0 VS Pengendalian & $0,25^{*}$ & $15,75^{*}$ \\
Mekanis VS (Sintetis \& Bioherbisida) & $0,07^{*}$ & $21,11^{*}$ \\
W1 VS (W2, W3, \& W4) & $0,56^{*}$ & $46,32^{*}$ \\
W2 VS (W3 \& W4) & $0,08^{*}$ & $16,16^{*}$ \\
W3 VS W4 & $0,04 \mathrm{~ns}$ & $1,59 \mathrm{~ns}$ \\
W5 VS (W6, W7, \& W8) & $0,03 \mathrm{~ns}$ & $2,26^{*}$ \\
W6 VS (W7 \& W8) & $0,01 \mathrm{~ns}$ & $0,08 \mathrm{~ns}$ \\
W7 VS W8 & $0,03 \mathrm{~ns}$ & $0,18 \mathrm{~ns}$ \\
W9 VS Pengendalian & $0,36^{*}$ & $116,27^{*}$ \\
\hline W0 (Tanpa pengendalian gulma) & $0,22 \mathrm{de}$ & $81,71 \mathrm{a}$ \\
W1 (Mekanis 1 MST) & $0,21 \mathrm{e}$ & $82,36 \mathrm{a}$ \\
W2 (Mekanis 1 \& 2 MST) & $0,69 \mathrm{bc}$ & $43,03 \mathrm{c}$ \\
W3 (Mekanis 1, 2 \& 3 MST) & $1,01 \mathrm{ab}$ & $16,79 \mathrm{~d}$ \\
W4 (Mekanis 1, 2, 3 \& 4 MST) & $1,09 \mathrm{a}$ & $9,42 \mathrm{~d}$ \\
W5 (Bioherbisida Bunga Kenikir) & $0,65 \mathrm{bc}$ & $46,27 \mathrm{c}$ \\
W6 (Herbisida Oksiflourfen 200 mL.m-2) & $0,45 \mathrm{~cd}$ & $62,92 \mathrm{~b}$ \\
W7 (Herbisida Oksiflourfen 300 mL.m-2) & $0,52 \mathrm{c}$ & $57,20 \mathrm{~b}$ \\
W8 (Herbisida Oksiflourfen 400 mL.m-2) & $0,45 \mathrm{~cd}$ & $62,56 \mathrm{~b}$ \\
W9 (Bebas gulma) & $1,31 \mathrm{a}$ & $0,00 \mathrm{e}$
\end{tabular}

Keterangan: angka yang diikuti tanda $\left({ }^{*}\right)$ berbeda nyata, angka yang diikuti huruf (ns) tidak berbeda nyata pada uji kontras dengan taraf kepercayaan 95\%; angka yang diikuti huruf yang sama pada kolom yang sama, tidak berbeda nyata pada uji DMRT pada taraf kepercayaan $95 \%$ 
Tabel 6 menunjukkan pengaruh perlakuan pengendalian gulma terhadap produktivitas dan kehilangan hasil tanaman kedelai. Diketahui bahwa produktivitas tanaman kedelai perlakuan tanpa pengendalian gulma (W0) berbeda nyata dibandingkan produktivitas tanaman perlakuan pengendalian gulma. Perlakuan yang menghasilkan produktivitas tanaman yang setara dengan perlakuan W0 adalah perlakuan W1, W6, dan W8. Perlakuan W1 menghasilkan produktivitas tanaman yang berbeda nyata dibandingkan dengan perlakuan W2 hingga W9. Perlakuan W3 memiliki produktivitas tanaman yang berbeda nyata dengan perlakuan W6, W7, dan W8. Sedangkan perlakuan W4 memiliki produktivitas tanaman yang berbeda nyata dibandingkan dengan perlakuan W5, W6, W7, dan W8. Berdasarkan data tersebut dapat diketahui bahwa perlakuan W3 dan W4 memiliki produktivitas yang setara dengan perlakuan W9.

Beralih pada parameter kehilangan hasil tanaman, dimana perbandingan kehilangan hasil tanaman antara perlakuan tanpa pengendalian gulma (W0) berbeda nyata dengan kehilangan hasil tanaman perlakuan pengendalian gulma. Diketahui hanya perlakuan W1 yang memiliki kehilangan hasil setara dengan perlakuan W0. Kehilangan hasil pada tanaman perlakuan W2 setara dengan kehilangan hail pada tanaman perlakuan W5. Kemudian kehilangan hasil pada tanaman perlakuan W3 setara dengan kehilangan hasil tanaman perlakuan W4. Kehilangan hasil yang dialami oleh perlakuan herbisida sintetis menunjukkan hasil yang setara. Sedangkan dari seluruh perlakuan yang diuji tidak ditemukan perlakuan yang mengalami kehilangan hasil yang setara dengan perlakuan W9.

Hasil penelitian menunjukkan bahwa hasil tanaman kedelai terbukti sangat dipengaruhi oleh perlakuan pengendalian gulma. Perlakuan W2, W3, W4, W5, W7 dan W9 terbukti mampu menghasilkan produktivitas tanaman lebih tinggi dibanding perlakuan W0. Produktivitas tanaman perlakuan W6, W7, dan W8 setara dengan perlakuan W2 dan W5. Produktivitas yang dihasilkan oleh tanaman perlakuan W2 dan W5 setara dengan perlakuan W3, tetapi berbeda nyata terhadap produktivitas tanaman perlakuan W4. Perlakuan W3 dan W4 mengahasilkan produktivitas tanaman kedelai yang setara dengan perlakuan bebas gulma (W9).

Perlakuan W3, W4 dan W9 efektif meningkatkan produktivitas dan menurunkan kehilangan hasil tanaman kedelai. Tetapi perlakuan W3 dinilai lebih efisien dibandingkan dengan perlakuan W4 maupun W9. Hal ini desebabkan karena perlakuan W3 menghasilkan produktivitas tanaman yang setara dengan perlakuan W4 dan W9 walau pengendalian gulma hanya dilakukan mulai umur 0 hingga 3 MST. Dengan hanya 
melakukan pengendalian gulma setiap minggu hingga 3 MST, perlakuan W3 akan lebih hemat waktu, tenaga, maupun biayan jika dibandingkan dengan perlakuan W4 dan W9.

\section{KESIMPULAN}

Perlakuan pengendalian gulma yang paling efektif dan efisien untuk menekan kompetisi yang disebabkan oleh keberadaan gulma pada tanaman kedelai adalah perlakuan W3, yakni pengendalian gulma secara mekanis setiap minggu hingga 3 MST yang mampu menghambat pertumbuhan gulma secara nyata, memberikan produktivitas kedelai setara dengan kontrol positif, dan persentase kehilangan hasil kedelai rendah.

\section{DAFTAR PUSTAKA}

Anonim. 2006. Karekteristik Kedelai Sebagai Pangan Fungsional. eBookPangan.com.

Atun, S. 2009. Potensi senyawa isoflafon dan derivatnya dari kedelai (Glycine max L.) serta manfaatnya untuk kesehatan. Prosiding Seminar Nasional, Pendidikan dan Penerapan MIPA, UNY.

Hafsah, S., M. A. Ulim, dan C. M. Nofayanti. 2012. Efek alelopati Ageratum conyzoides terhadap pertumbuhan sawi. Jurnal Floratek 8:18-24

Hendrival, Z. Wirda, dan A. Aziz. 2014. Periode kritis tanaman kedelai terhadap persaingan gulma. Jurnal Floratek 9: 6-13.

Johny, M. 2006. Dasar - dasar Mata Kuliah Gulma. Universitas Udayana, Bali.

Lim, T. K. 2014. Edible Medicine and Non-Medicine Plants. Springer.

Radjit, B.S. dan R.D. Purwaningrahayu. 2016. Pengendalian Gulma pada Kedelai. Balai Penelitian Tanaman Kacang - kacangan dan Umbi - umbian. Malang.

Riniarsi, D. 2015. Outlook Komoditas Pertanian Tanaman Pangan Kedelai. Pusat Data dan Sistem Informasi Pertanian, Kementerian Pertanian.

Roviyanti, F. dan E. Widaryanto. 2018. Efikasi herbisida oksiflourfen terhadap gulma serta pengeruhnya pada pertumbuhan dan hasil tanaman brokoli (Brassica oleraceae L. var. Italica). Jurnal Produksi Tanaman 6: 331 - 340.

Sukman. 2003. Gulma dan Teknik Pengendaliannya. Rajawali Pers. Jakarta. 